\title{
Influence Of Elderly Gymnastics On Fitness Level In Work Area Of Puskesmas Rami Kelurahan Source Jaya Siantar Martoba Pematangsiantar City 2017
}

\author{
Namora Lumongga Lubis ${ }^{1}$, Kindi Meiastrina ${ }^{2}$ \\ 1 Staff Lecturer of Program Studies of Health Sciences of Society of USU \\ 2 Alumni Master Program of Public Health Studies STIKes DHDT
}

\begin{abstract}
An increased proportion of elderly people needs to get attention because the elderly group is a high-risk group who experience various health problems, especially degenerative diseases. When entering elderly, the functions can no longer function properly, then the elderly need a lot of help in living activities of life, by doing sports such as advanced gymnastics can prevent or slow functional loss. The study aims to determine the influence of elderly gymnastics on the level of fitness in the work area of Rami village health sub-district of Siantar Martoba Pematangsiantar in 2017. The research is queasy experiments using one group pretest-postest design. Sampling method uses Non Randong Sampling with Purposive Sampling technique. The number samples for this study are 70 people. The data were analyzed by using Wilcoxon Rank Test statistic test with $95 \%$ confidence value and the significant value $\alpha=0,05$. The result showed that the average difference of walking for 6 minutes after and before have elderly gymnastics is 16,69 meters, with bivariate analysis, found the influence of elderly gymnastics toward fitness level in the work area of Public Health Center of Rami the village of Sumber Jaya sub-district of Siantar Martoba Pematangsiantar in 2017 with p-value = was $0,000<\alpha=0,005(5 \%)$. The elderly should be able to take advantage of elderly gymnastics as one means of fitness and health care workers in order to participate to keep performing elderly gymnastics so that the elderly can keep maintaining fitness.
\end{abstract}

Keywords: Elderly, Elderly Gymnastic, Level of Fitness

\section{PRELIMINARY}

Improving science and technology, especially in the medical and medical field will affect the health quality of the population and increase the life expectancy of humans which resulted in the increasing number of elderly.

The impact is an increase in life expectancy from 59.8 years in 1990 to 71.7 in 2020. In addition, based on statistical data in 1993, the elderly population in Indonesia is predicted to increase $414 \%$ or four-fold by 2025 compared to 1990 and This result is the highest in the world.

The number of elderly people in Indonesia in 2000 is projected at $7.28 \%$ and in 2020 to about $11.34 \%$. Population projection by statistic center of the year 2005-2010 amount of elderly will equal to a number of children under five, that is about 19 million people or 8,5\% from the entire population. Efforts that have been done by the government in providing health services to the elderly include five health efforts namely, promotion/promotion, early diagnosis and early diagnosis and prompt treatment, disability limitation, and recovery / rehabilitation.
Increasing the proportion of elderly people needs attention because the elderly group is a high-risk group with various health problems, especially degenerative disease (MOH RI, 2007).

When entering old age, the body functions can no longer function properly, then the elderly need a lot of help in living activities - life activities. Not to mention the degenerative diseases that accompany elderly circumstances make them require extra attention from the people around them, by doing sports like elderly gymnastics can prevent or slow down the functional loss (Darmojo, 2004).

In general, fitness is physical fitness (physical fitness), the ability of a person to perform daily work efficiently without excessive fatigue so that it can still enjoy his spare time (Irianto, 2004). An exercise is a form of physical exercise that gives a good (positive) effect on the level of a person's physical ability if done properly and correctly (MOH, 2001).

Sports activities will help the body stay fit and fresh because it keeps the bones strong, encourages the heart to work optimally, and helps remove free radicals that roam the body, in other 
words have a good physical fitness if the heart and blood circulation well so that the whole body can run Function for a long time. (Sumosardjuno, 1998).

The likelihood of functional dependence on inactive elderly will increase by $40 \%-60 \%$ compared to healthy elderly and physically active, therefore elderly need to do gymnastics in order to improve the physical condition of elderly and can reduce functional dependence (Darmojo, 2004). However, this elderly fitness is also influenced by age and gender. An elderly with an increasingly dusk age will occur chronic degenerative diseases progressively progressive (Darmojo, 2004).

Mental changes in entering old age will contribute to one's health. An ambitious personality type, feeling pursued by the task and always ambitious should be more advanced, generally when entering old age tend to be anxious, easy to stress, anxiety, easily frustrated, feel underestimated, not ready to live at home. Conversely, those who are quiet personality, the desire to advance is balanced with unhurried efforts based on quiet thinking generally do not show negative mental changes, they are clever to be grateful for all forms of life and always think positive (Wirakusumah, 2000).

This study aims to determine the influence of Elderly Gymnastics Against Fitness Level in the Working Area of Rami Public Health
Village of Sumber Jaya Sub District Siantar Martoba City Pematangsiantar Year 2017.

\section{METHOD}

The type of this study was QuasyExperiments using a one-pretest-posttest design group to identify fitness levels before and after elderly gymnastics. The population in this study is all healthy elderly counted 86 people. Sampling method using Non-Random Sampling with Purposive Sampling technique is sampling based on the consideration of the researcher himself. The sample obtained is 70 people.

The location of this research is in working area of Rami Health Center Jalan Medan Km 4.5 Sumber Jaya Subdistrict, Siantar Martoba Subdistrict, Pematangsiantar City and research time is March-May 2017.

Methods of data collection in this study include primary data and secondary data. Primary data is data obtained directly from respondents through direct interview using questionnaire. Secondary data is data supporting primary data obtained from Rami Public Health Center.

Prior to hypothesis testing, it must be known data normality by using Pearson Product Moment with Kolmogorov Smirnov Test. Test results of data normality

\begin{tabular}{|l|c|c|c|c|c|c|}
\hline Variable & \multicolumn{3}{|c|}{ Kolmogorov-Smirnova } & \multicolumn{3}{c|}{ Shapiro-Wilk } \\
\cline { 2 - 7 } & Stat & Df & Sig. & Stat & Df & Sig. \\
\hline $\begin{array}{l}\text { Fitness level } \\
\text { before gymnastics }\end{array}$ &, 485 & 70 &, 000 &, 518 & 70 &, 000 \\
$\begin{array}{l}\text { Fitness Level } \\
\text { After Gymnastics }\end{array}$ &, 265 & 70 &, 000 &, 863 & & \\
& & & & & &, 000 \\
\hline
\end{tabular}

Fitness level before gymnastics sign. = $0,000<0,05$ then the data is not normally distributed. Fitness level after gymnastics sign. = $0,000<0,05$ then the data is not normally distributed. The normality assumption of data in this study is not met then used different test by using Wilcoxon Rank Test Test

\section{RESULTS}

Puskesmas Rami is the main health center located at Jalan Medan Km 4.5 Simpang Kerang Kelurahan Sumber Jaya, Siantar Martoba Subdistrict, Pematangsiantar City. The scope of the work area of Rami Puskesmas consists of three urban villages namely Sumber Jaya, Nagapita and Nagapitu Villages.

1. Univariate Analysis Based on the results of research most of the respondents aged 60- 
64 years are $60 \%$ (42 people), most of the respondents are female $(88.6 \% \quad(62$ people), most respondents have Type A personality type that is $65.7 \%$ (46 people). The level of fitness before the elderly gymnastics most respondents are not fit as much as $80 \%$ (56 people) and fitness level after gymnastics elderly most of the respondents fit as much as $88.6 \%$ (62 people).

2. Bivariate Analysis

Based on the research results can be concluded the average walking distance for 6 minutes before the elderly gymnastics is 45.74 meters while the walking distance for 6 minutes after the elderly gymnastics is 62.43 meters. The difference in the average distance of walking for 6 minutes after and

before the elderly gymnastics is 16.69 meters.

\section{Influence of Elderly Gymnastics Against Fitness Rate Before and After Elderly Gymnastics}

\begin{tabular}{|c|c|c|c|}
\hline \multicolumn{2}{|l|}{ Variable } & (Z) & $p$ \\
\hline Fitness & & - & 0 \\
\hline Level After & 6 & 7,173 & ,000 \\
\hline Gymnastics - & & & \\
\hline Fitness Rate & & & \\
\hline Before & & & \\
\hline Gymnastics & & & \\
\hline Total & & & \\
\hline
\end{tabular}

The results showed there were 66 respondents whose fitness level after doing gymnastics became more increased, while 4 respondents whose fitness level decreased after doing gymnastics. The Wilcoxon test results show the p-value of $0.000<\alpha=0.005(5 \%)$ so that the hypothesis decision is to accept the hypothesis which means there is the influence of fitness level before and after elderly gymnastics.

\section{DISCUSSION}

Statistical test results obtained from 70 respondents, there are 66 respondents whose fitness level after doing gymnastics become more increased, while 4 respondents whose fitness level decreased after doing gymnastics. Value p-value $0,000<\alpha=0.005(5 \%)$ which means there is influence of fitness level before and after elderly gymnastics.

Referring to the results of statistical tests can be explained that the elderly gymnastics affect the level of fitness. Sports activities will help the body stay fit and fresh because it keeps the bones strong, encourages the heart to work optimally, and helps remove free radicals that roam the body, in other words have a good physical fitness if the heart and blood circulation well so that the whole body can run Function for a long time. (Sumosardjuno, 1998).

The types of exercises that can improve and nurture a person's fitness are exercises that contain the elements of motion as a component of fitness, the duration of the exercise whenever done in a certain time. The intensity of the exercise meets the frequency of exercise each week is sufficient. Gymnastics with low-moderate intensity is the right type of exercise for the elderly to achieve fitness (Irianto, 2004).

\section{CONCLUSION}

There is the influence of elderly gymnastics to the level of fitness before and after performed elderly gymnastics in work area of Rami Public Health Village Sumber Jaya Subdistrict Siantar Martoba District Pematangsianta City, with p-value equal to $0.000<\alpha(0,05)$.

\section{SUGGESTION}

For Further Researcher is expected to use research with 2 groups of samples in order to obtain better results. Another thing to note is to use additional data such as observations and interviews to make the results more in-depth and perfect.

For the elderly, elderly should be able to utilize elderly gymnastics as one means of fitness treatment so that the quality of life is increased and to be able to move more elderly gymnastic activities in Sumber Jaya Village to be held at Posyandu Lansia on the 10th of every month. 
For Educational Institutions it is expected that educational institutions can use the results of this research as a foothold for further research.

For Research Sites it is hoped that this research can be used by health officers to participate in conducting gymnastics scheduled every week, to be able to discuss with elderly to schedule elderly gymnastics together with elderly.

\section{BIBLIOGRAPHY}

Arikunto, S. (2006). Research Procedures A Practice Approach. Jakarta: PT. Rineka Cipta

Azwar. (2003). Qualitative Research Methodology. Bandung: Rosdakarya

Bitter V. Role of the 6-Minute Walk Test in Cardiac Rehabilitation. Humana Press, Totowa New Jersey 2007: 131-139

Brick, L. (2001). Fresh with Tera Gymnastics. Jakarta: Raja Grafindo

MOH RI, (2001). Cross-Sectoral Partnership Guidance Under Adult Lifting. Jakarta

(2007). Healthy Indonesia Indicator 2010

and Guidelines for the Establishment of Healthy Provinces and Healthy Regency / City Indicators. Jakarta

רררבררררררר (2009). Indonesia Health

Profile. Jakarta: Department of the Republic of Indonesia

Darmojo, R.B. Martono, H.H, (2004). Geriatric Handbook. Jakarta: Publisher Hall FKUI

Handayani, Sus. (2013). Differences of Elderly Fitness Before and After Performed Elderly Gymnastics in Leyangan Village District of East Unggaran Semarang Regency. Http: //www.perpusnwu.web.id-pdf (6 February 2017)

Iqbal, Muhammad, (2007). Satisfactory Service. Jakarta: PT. Elex Media Komputindo
Irianto, A. (2004). Teleostei Fish Pathology. Gadjah Mada University Press

Maryam, R. Siti \& et al (2008). Getting to Know the Elderly and the Treatment. Jakarta: Salemba Medika

Mood, Alexander M. et. (1998). Introduction to Theory of Statistics. Mc Graw Hill International

Murwani, Arita. (2010). Nursing Family Care. Jakarta: Mitra Cendekia Press

Ni Made Parwati, et al (2013). Tera Indonesia's Gymnastics Improves Lung Heart Health at Wanti Panti Wana Seraya Denpasar. Public Health and Preventive Medicine Archive, Volume 1, Number 1, July 2013

Notoadmodjo, S. (2012). Health Research Methodology. Jakarta: PT. Rineka Cipta

Nugroho, W. (2008). Gerontik and Geriatrik. Jakarta: EGC

Rahmi, U., Somatri, B., \& Alifah, N. Y N. (2016). Illustration of Elderly Knowledge About Elderly Gymnastics at Social House Tresna Werdha Budi Pertiwi. Journal of Nursing Education Indonesia Vol.2 No.1 July 2016

Sarafino, E. P (2006). Health Psychology Biopsychosocial Interactions. 5th edition. United States of America: John Wiley \& Sons, Inc.

Schultz, D \& Schultz, S. E, (1994). Theories of Personality. 5th edition. California: Wadsworth, Inc.

Setiawan. (2004). The methodology of Midwifery Research. Jakarta: Nuha Medika

Setyonegoro, Kusmanto, Yus Iskandar, (1985). Biological Psychiatry: Mianserine And Depression. Jakarta: Dharma Graha Press

Sinaga, Relina. (2013). Effect of Osteoporosis Gymnastics on Increasing Physical Activity of Seniors at Glugus Puskesmas Medan City Year 2013. Universitas Sumatera Utara 
Sumintarsih. (2006). Fitness for the Elderly. Sports, $147-160$

Sumosardjono, (1992). Knowledge and Sports. Jakarta: Ministry of Education and Culture

Suroto. (2004). Handbook Lecture on Understanding Gymnastics, Benefits of Gymnastics, and Movement Sequence. Semarang: Technical Implementation Unit of Undip General Sport Course

Suyanto. (2009). Midwifery Research. Jogjakarta: Mitra Cendika Press

Taylor, S.E, (2003). Health Psychology. 5th edition. Los Angeles: McGraw-Hill, Inc.

Westcott, Wayne L, Thomas R. Baechle. (1999). Back Fit After Fifty. Jakarta: PT. Raja Grafindo Persada

Wirakusumah, Emma S. (2000). Stay Fluent in the Elderly. Jakarta: Trubus Agriwidya

Yefta Primasari, et al. (2015). Relationship Personality Type With Physical Activity Levels In The Elderly In Panti Werdha Bhakti Luhur Branch of Sidoarjo. Http://www.stikeshangtuah-sby-.ac.id (23 February 2017)

Yustika, Nur Ichsana. (2016). The Influence of Elderly Gymnastic Against Aged Elderly At Posyandu Seni Tegalsari and Posyandu Seni Lodalang Siswodipuran Boyolali. muhammadiyah Surakarta university 